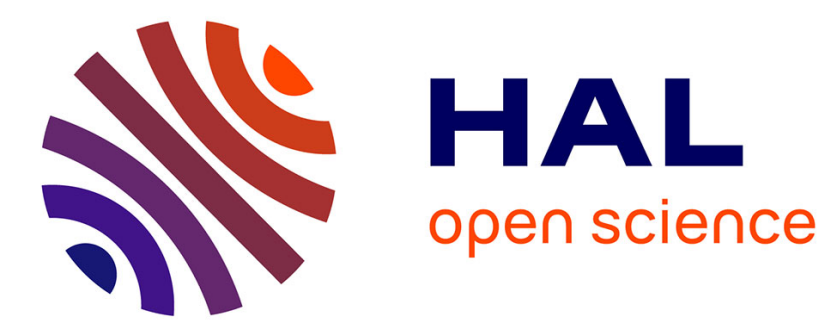

\title{
Managing food price volatility in a large open country: the case of wheat in India
}

Christophe C. Gouel, Madhur Gautam, Will J. Martin

\section{To cite this version:}

Christophe C. Gouel, Madhur Gautam, Will J. Martin. Managing food price volatility in a large open country: the case of wheat in India. Oxford Economic Papers, 2016, 68 (3), pp.811-835. 10.1093/oep/gpv089 . hal-01581612

\section{HAL Id: hal-01581612 \\ https://hal.science/hal-01581612}

Submitted on 5 Oct 2017

HAL is a multi-disciplinary open access archive for the deposit and dissemination of scientific research documents, whether they are published or not. The documents may come from teaching and research institutions in France or abroad, or from public or private research centers.
L'archive ouverte pluridisciplinaire HAL, est destinée au dépôt et à la diffusion de documents scientifiques de niveau recherche, publiés ou non, émanant des établissements d'enseignement et de recherche français ou étrangers, des laboratoires publics ou privés.

\section{다(1)(2)}

Distributed under a Creative Commons Attribution - ShareAlike| 4.0 International 


\title{
Managing food price volatility in a large open country: the case of wheat in India*
}

\author{
By Christophe Gouel ${ }^{\mathrm{a}}$, Madhur Gautam ${ }^{\mathrm{b}}$, and Will J. Martin ${ }^{\mathrm{c}}$
}

á́conomie Publique, INRA, 16 rue Claude Bernard, 75005 Paris, France and CEPII; e-mail: christophe.gouel@grignon.inra.fr

${ }^{\mathrm{b}}$ Agriculture Global Practice, The World Bank, 1818 H Street NW, Washington DC 20433, USA; email: Mgautam@worldbank.org

${ }^{c}$ International Food Policy Research Institute (IFPRI), 2033 K Street NW, Washington DC 20006, USA; e-mail: w.martin@cgiar.org

\begin{abstract}
India has pursued an active food security policy for many years using a combination of trade policy interventions, public distribution of food staples, and assistance to farmers through minimum support prices defended by public stocks. This policy has been quite successful in stabilizing staple food prices, but at a high cost, and with potential risks of unmanageable stock accumulation. Based on a rational expectations storage model representing the Indian wheat market and its relation to the rest of the world, we analyse the cost and welfare implications of this policy and unpack the contribution of its different elements. To analyse alternative policies, we assume that social welfare includes an objective of price stabilization and assess optimal policies corresponding to this objective. We consider fully optimal policies under commitment as well as optimal simple rules and show that adopting simple rules can achieve most of the gains from fully optimal policies.
\end{abstract}

JEL classification: F13, O13, Q11, Q17, Q18.

\footnotetext{
* This is a pre-copyedited, author-produced PDF of an article accepted for publication in Oxford Economic Papers following peer review. The version of record "Gouel, C., M. Gautam, and W.J. Martin (2016). Managing Food Price Volatility in a Large Open Country: The Case of Wheat in India. Oxford Economic Papers, 68(3), 811835 " is available online at: http://doi.org/10.1093/oep/gpv089.
} 


\section{Introduction}

India has aggressively pursued food security for many years. For India's policy makers, the prices of staple foods-particularly wheat and rice-raise major concerns. To protect poor consumers from high prices, and to lower the cost of food in normal times, a Public Distribution System (PDS) provides food to low-income consumers at concessional prices. To protect producers from low prices, a pre-announced Minimum Support Price (MSP) places an effective floor on domestic prices, defended by the government's accumulation of staple food stocks. India also pursues an active trade policy to insulate the domestic market from fluctuations in world prices of these staples. Together, these policies have stabilized domestic prices, but concern is growing over the policies' mounting costs, potential inefficiencies, and the stark juxtaposition of large and growing public stocks with rising food prices (Basu, 2011).

Concern about food prices is common in countries with many poor people who are vulnerable to price spikes or price slumps. In that context, policy makers often favor policies that reduce the volatility of staple food prices. Such policies have been especially prevalent since the 2007/08 world food crisis, which highlighted the potential instability in world food markets (Demeke et al., 2009; Gouel, 2014).

This study looks at alternatives to address some of the challenges facing policy makers in these situations. Based on the assumption that policy makers seek to maximize social welfare, and specifically taking into account their dislike for price volatility, this study assesses current policies for wheat in India and then examines alternatives. The analysis relies on a rational expectations model of storage and trade that represents two regions-India and the rest of the world-and their interaction on the wheat market. The economic agents in the model include producers, consumers, and holders of stocks. Producers base their planting decisions on expected prices at harvest time. Stock holders make decisions on how much to store from one year to the next based on the price they expect next year, the price of grain this year, and the cost of storage. International trade is represented by spatial arbitrage conditions. Current policies are incorporated by identifying patterns that enable them to be represented as simple rules, defined as functions of world and domestic conditions. The model is calibrated using 2012 data on India's wheat market and solved numerically.

Alternative stabilization policies are designed based on the maximization of a social welfare function that includes a quadratic loss function in prices. In addition to a fully optimal policy, which gives welfare-maximizing levels of storage and trade in all situations, the use of simple rules of intervention is also considered. Past research suggests that simple rules might yield a large share of the benefits of an optimal policy (Gouel, 2013b) while being easier to design and to implement. The simple rules considered are a constant subsidy to private storage and trade tariffs defined by an isoelastic function of the border price. 
A final issue addressed in the study is the cost of public storage in India, which appears to be much higher than in other countries. With such high costs, public storage is extremely difficult to justify on economic grounds. It would be far less costly to rely on domestic private storage or on world trade and storage abroad.

Beyond the analysis of current and alternative policies for wheat in India, this study contributes to the literature on the design of food price stabilization policies (Gouel, 2013a, 2013b; Gouel and Jean, 2015). It augments the modelling undertaken for previous studies by considering the case of a large country. Modelling a large-country case makes it possible to assess the effect of counter-cyclical policies on the world market, a very contentious issue since the $2007 / 08$ spikes in food prices, which were partially precipitated by widespread use of export restrictions (Martin and Anderson, 2012). A second contribution of this study is that it confirms, for an open-economy setting, Gouel's (2013b) results that optimal simple rules can achieve welfare gains close to those from fully optimal rules. Optimal simple rules are found to be slightly less successful in an open economy setting compared to a closed economy setting, however, because they do not exploit the country's market power as do fully optimal policies.

After the main features of India's wheat market are outlined in Section 2, Section 3 develops the model representing India's wheat market and its relation to the world market. A representation of welfare in this framework is proposed, taking into account the observed preference for food price stability (Section 4). A core assumption is that the cost of risk to policy makers rises more than proportionately with deviations from the mean price. Section 5 begins by considering the mathematical representation of current policies and the design of alternative stabilization policies. The objective function and the structure of the model make it possible to identify a set of optimal policies that minimize the costs of any given degree of volatility. Simple rules of intervention are considered as well. Section 6 develops a numerical calibration for the model and presents the numerical results. Section 7 presents the conclusions.

\section{India's wheat market}

India has undergone a major transformation since the 1960s, from being a highly insecure food importer to a consistent net-exporter of agricultural products (Gulati et al., 2013), and from a policy framework that discriminated against agriculture to a relatively more neutral domestic policy regime (Pursell et al., 2009). The evolution of India's wheat market reflects this profound transformation-from being a chronic food-aid recipient to an often substantial net-exporter (Fig. 1, left panel).

Traditionally India has sought to achieve food security through actions to ensure that food is available and accessible. Policy has focused on an aggressive drive toward self-sufficiency in food grains, encompassing comprehensive support to farmers through the introduction of improved varieties and inputs; rapid expansion of irrigated area; subsidies of various inputs; 
efforts to maintain relatively stable producer prices; and management of the long-run relationship between domestic and world prices.

Protecting poor consumers through stable market prices and access to subsidized food has been another major feature of India's food policy. Aside from these interventions, for decades the government has maintained public stocks of food grains to buffer against production shocks, assist in maintaining national food self-sufficiency, stabilize food prices, and supply the PDS. These policies are supplemented with highly interventionist trade policies that rely on a combination of tariffs and periodic quantitative restrictions.

With higher and more stable output, the government is compelled to procure increasing volumes of wheat at the pre-announced MSP. It acquires wheat early in the marketing season and then uses the accumulated stocks throughout the year to supply the PDS. Since the quantities procured at the minimum price may exceed the needs of the PDS, it is necessary at times to dispose of excess stocks. These releases are made on a discretionary basis, however, and as Basu (2011) explains, an emphasis on selling the stored grains at prices that cover the purchasing price and storage costs frequently makes it impossible to dispose of stocks in this way. Another impediment to effective open market sales is the possible degradation of quality due to inadequate storage facilities. Basu also notes that releases often fail to occur in periods of high prices. On occasion, the excessive accumulation of stocks requires the government to export its stocks, including by writing down the price, as reportedly done in 2002-03 (GaneshKumar et al., 2012).

From 2007, during several years of high world prices, India used trade barriers to restrict grain exports and keep domestic prices down. The net outcome of these actions, together with public procurement, has been a substantial rise in stocks (Fig. 1, right panel). The trade policy measures pushed domestic prices down relative to world prices, making the MSP the effective market price and requiring increases in stocks to support this price. Trade and stockholding policies appear to have been working against each other during this period, with trade policies holding down domestic prices while stock accumulation in support of the MSP drove them up.

\section{Core model: The laissez-faire situation}

A rational expectations two-country storage-trade model (similar to Larson et al., 2014, and following the first development of a storage trade model by Williams and Wright, 1991, Ch. 9) is used to model the market for wheat in the absence of any intervention - a context in which behaviour does not follow from government decisions but from the economic responses of decentralized firms and consumers. It is a partial equilibrium model, representing the behaviour in each country of competing stock holders, producers, and consumers. This model is a departure from previous studies on India (such as Srinivasan and Jha, 2001) in that it represents the rest of the world (RoW) not as an exogenous price process but as a single large "country" 
with its own demand and stochastic supply. This specification is important for two reasons. First, a storage model is a better representation of world price dynamics than any simple dynamic process (Cafiero et al., 2011). Second, although the policy response of the RoW is not modelled, important feedback effects between India's food policy and the behaviour of the RoW take place through the reactions of private stock holders and producers in India and abroad. These effects can be accounted for only if all agents are explicitly represented. With respect to the RoW, India represents a large share of the market, so India's stabilization policies affect the world market.

Regions RoW and India are indicated by the superscript $r \in\{w, i\}$. Producers make their production choices and pay for inputs one period before bringing output to market. However, actual production is uncertain. The difference between planned and actual production is a random shock, which is the source of volatility that drives price volatility in the model. The production decision is based on maximization of expected profit given by:

$$
\Pi_{t \mid t+1}^{r}=\delta E_{t}\left(P_{t+1}^{\mathrm{r}} \bar{H}_{t}^{\mathrm{r}} \epsilon_{t+1}^{r}\right)-\Psi^{\mathrm{r}}\left(\bar{H}_{t}^{\mathrm{r}}\right),
$$

where $P_{t}^{r}$ is the price; $\Psi^{\mathrm{r}}\left(\bar{H}_{t}^{\mathrm{r}}\right)$ is the cost of planned production level $\bar{H}_{t}^{\mathrm{r}}$, which is affected in $t+1$ by the multiplicative random disturbance $\epsilon_{t+1}^{r} ; \delta$ is the discount factor; and $E_{t}$ is the mathematical expectations operator conditional on information available at time $t$. Profit maximization by producers gives the following intertemporal equation:

$$
\delta E_{t}\left(P_{t+1}^{r} \epsilon_{t+1}^{r}\right)=\Psi^{r^{\prime}}\left(\bar{H}_{t}^{r}\right) .
$$

Competitive stock holders' behaviour is defined by the following condition: ${ }^{1}$

$$
S_{t}^{r} \geq 0 \perp P_{t}^{r}+k^{r}-\delta E_{t} P_{t+1}^{r} \geq 0,
$$

where $S^{r}$ denotes private stock levels and $k^{r}$ storage costs. The implication is that storage occurs when the returns to storage, net of the time value of money and physical storage costs, are expected to be positive. Competitive storage takes place when the returns to holding stocks are expected to equal or exceed the cost of holding stocks.

Unless policies otherwise intervene, trade takes place between the two markets, and the world price is endogenously determined. Differences between production, consumption, and storage in the two regions are balanced by trade. Trade is decided by the spatial arbitrage condition:

$$
X_{t}^{r} \geq 0 \perp P_{t}^{\mathrm{r}}+\theta_{r, s} \geq P_{t}^{s} \text { for } s \neq r,
$$

where $X^{r}$ denotes the exports from $r$ and $\theta_{r, s}$ the transport cost from $r$ to $s$.

\footnotetext{
${ }^{1}$ The "perp" notation $(\perp)$ used in the complementarity condition means that the expressions on either side of the sign are orthogonal, so that if one equation holds as a strict inequality, the remaining side holds as a strict equality.
} 
The model has two state variables: the availability in both countries, $A_{t}^{r}$, defined as the sum of production and private carry-over:

$$
A_{t}^{r} \equiv S_{t-1}^{r}+\bar{H}_{t-1}^{r} \varepsilon_{t}^{r}
$$

Market equilibrium can be written as:

$$
A_{t}^{r}+X_{t}^{s}=D^{r}\left(P_{t}^{r}\right)+S_{t}^{r}+X_{t}^{r} \text { for } s \neq r
$$

The demand function is assumed to be isoelastic: $D^{r}\left(P_{t}^{r}\right) \equiv d^{r} P_{t}^{r^{\alpha^{r}}}$, where $d^{r}>0$ is a scale parameter and $\alpha^{r} \geq 0$ is the demand elasticity, and the marginal cost function is assumed to be linear: $\Psi^{r^{\prime}}\left(\bar{H}_{t}^{r}\right) \equiv a^{r}+b^{r} \bar{H}_{t}^{r}$, where $a^{r}$ and $b^{r}>0$ are the intercept and slope of the marginal cost function.

To summarize, the problem has two state variables, $\left\{A_{t}^{r}\right\}$, and eight response variables, $\left\{P_{t}^{r}, S_{t}^{r}, \bar{H}_{t}^{r}, X_{t}^{r}\right\}$, for $r \in\{i, w\}$.

\section{Welfare and public costs}

The welfare and public costs of policy interventions are evaluated initially based on standard sums of surplus measures of welfare. Given the absence of market imperfections in the laissezfaire model, it is important to note that the introduction of any public policy, such as interventions to reduce price volatility, can be expected to decrease welfare (at least global welfare, as India could possibly improve its welfare at the expense of the RoW by manipulating its terms of trade, as long as other countries did not retaliate). To guide the design of alternative price stabilization policies, an alternative welfare measure, which introduces a preference for reducing price risk, is used.

The public costs of the food security policy include the cost of public storage and the cost of trade policy, as well as a combination of these costs. The cost of the PDS is not included in the cost of public storage. This is an important distinction. The quantity of grain that is stored and not released domestically is a choice that affects market prices by changing the quantity of grain entering the market. The quantity of grain purchased for resale to low-income consumers has a quite different effect. It exerts an impact on domestic prices only to the extent to which the redistribution from taxpayers to poor consumers results in an increase in aggregate demand for grain. 


\subsection{Standard welfare measure}

A standard measure of instantaneous welfare, $w_{t}^{r}$, is provided in each country by the sum of consumers' surplus, producers' surplus, and private stock holders' surplus, minus the cost of stabilization policies: ${ }^{2}$

$$
w_{t}^{r}=-d^{r} \frac{P_{t}^{r 1+\alpha^{r}}}{1+\alpha^{r}}+P_{t}^{r} \bar{H}_{t-1}^{r} \epsilon_{t}^{r}-a^{r} \bar{H}_{t}^{r}-\frac{b^{r} \bar{H}_{t}^{r^{2}}}{2}+P_{t}^{r} S_{t-1}^{r}-\left(k^{r}+P_{t}^{r}\right) S_{t}^{r}-\operatorname{Cos}_{t}^{r},
$$

where $\operatorname{Cost}_{t}^{r}$ is the cost of stabilization policies, described below. Using (5), eq. (7) can be simplified to

$$
w_{t}^{r}=-d^{r} \frac{P_{t}^{r^{1+\alpha^{r}}}}{1+\alpha^{r}}+P_{t}^{\mathrm{r}} A_{t}^{r}-a^{r} \bar{H}_{t}^{r}-\frac{b^{r} \bar{H}_{t}^{r^{2}}}{2}-\left(k^{r}+P_{t}^{r}\right) S_{t}^{r}-\operatorname{Cost}_{t}^{r} .
$$

The costs associated with India's stabilization policies are expressed as the sum of storage and trade costs, defined as:

$$
\operatorname{Cost}_{t}^{i}=\operatorname{Cost}_{t}^{i, S}+\operatorname{Cost}_{t}^{i, T r}
$$

\subsection{A welfare measure including preference for food price stability}

As the laissez-faire model in the previous section does not include any market imperfections, the standard surplus-based welfare measure does not take into account any preference for food price stability. To account for it, a quadratic term in the domestic price is introduced into the welfare measure for India:

$$
w_{t}^{i}=-d^{i} \frac{P_{t}^{i^{1+\alpha^{i}}}}{1+\alpha^{i}}+P_{t}^{i} A_{t}^{i}-a^{i} \bar{H}_{t}^{i}-\frac{b^{i} \bar{H}_{t}^{i^{2}}}{2}-\left(k^{i}+P_{t}^{i}\right) S_{t}^{i}-\operatorname{Cos}_{t}^{i}-\frac{K}{2}\left(P_{t}^{i}-\bar{P}^{i}\right)^{2}
$$

where $K \geq 0$ is a parameter characterizing the social preference for price stability and $\bar{P}^{i}$ is a target price around which the Government of India wishes prices to be stabilized. $\bar{P}^{i}$ is taken to be the steady-state, laissez-faire price-the price when shocks are equal to their expectations and when countries do not use storage and trade policies.

Although the quadratic term is merely a means of introducing (in a tractable way) additional concavity in the social welfare function, it can also be given some micro-foundations by being interpreted as the second-order approximation of the difference between the equivalent variation of a risk-averse consumer and its surplus, so it would be the welfare term accounting for non-zero risk aversion and income elasticity. Following Turnovsky et al. (1980), $K$ would

\footnotetext{
${ }^{2}$ Consumers' surplus is derived as $C S=\int_{P}^{\bar{P}} D(p) \mathrm{d} p=\left[d p^{1+\alpha} /(1+\alpha)\right]_{P}^{\bar{P}}=d\left(\bar{P}^{1+\alpha}-P^{1+\alpha}\right) /(1+\alpha)$, so abstracting from the term in $\bar{P}$, which is independent from policy choice, leads to the expression used in the social welfare function.
} 
in this case be equal to $\gamma(R-v) D^{i}\left(\bar{P}^{i}\right) / \bar{P}^{i}$, where $\gamma, R$, and $v$ are, respectively, values at steady state of the commodity budget share, risk aversion relative to income risk, and income elasticity. $K$ would be positive if risk aversion is higher than income elasticity, which seems reasonable for staple food products. This would represent an approximation of social welfare for an incomplete-market economy in which risk-averse consumers cannot insure against food price risk (see Gouel and Jean, 2015, for such an interpretation). This interpretation is useful for choosing reasonable values for $K$.

\section{Price stabilization policies}

This section begins by incorporating India's current wheat policies in the analytical model. As noted, these policies target the three main channels for price stabilization-production, storage and trade. Next, the derivation of optimal price stabilization polices is outlined, followed by proposals for some optimal simple rules that might serve as a more realistic, practical policy alternatives. The social welfare outcomes under the optimal simple rules are then compared to those under the fully optimal policies to test how well they perform.

\subsection{India's current wheat policies}

India's current trade and storage policies are challenging to introduce in a rational expectations model. They are adjusted regularly at the discretion of the government, depending on prevailing market conditions and policy makers' assessment of which changes are required. They are spatially heterogeneous: states can put a mark-up on the MSP of the central government, and inter-state trade can be restricted or submitted to taxes. They also create incentives that are difficult to model. For example, grains from the PDS are probably of lower quality than grains from the market, because of poor storage conditions and lack of incentives to procure highquality grains.

To analyse the effects of these policies, they have to be represented in the model as rules that respond in a predictable manner to the market context, so that agents can form expectations about them. For modelling purposes, the rules have to be simple. They are designed to capture the essence of the policies while abstracting from the complexity of the actual policies. The model thus aims to represent the indicative impacts of current policies rather than to provide precise figures. ${ }^{3}$ The following sections describe how the main structural characteristics of current policies are incorporated into the model.

\subsubsection{Storage policy and the PDS}

Public stocks are built up largely through purchases at the announced MSP. For simplicity, and given that the model focuses on price volatility stemming from production shocks (domestic

\footnotetext{
${ }^{3}$ For another approach, see Kozicka et al. (2015) where India's policies are represented using reduced-form econometric equations.
} 
and foreign), the MSP is assumed to be constant and equal to the steady-state price, which is the price in the absence of shocks - that is, under normal harvest and demand conditions. In the model, the MSP therefore plays the role of a floor price that the government defends through public storage. Public stock accumulation, $\Delta S^{G+}$, is governed by

$$
\Delta S_{t}^{G+} \geq 0 \perp P_{t}^{i}-M S P \geq 0 .
$$

The critical influence on the market is the difference between government stock purchases, $\Delta S_{t}^{G+}$, and releases under the PDS, $\Delta S_{t}^{G-}$. Accounting for public stock purchases and releases, the Indian market clearing equation is adjusted as follows with respect to the laissez-faire model:

$$
A_{t}^{i}+X_{t}^{\mathrm{w}}+\Delta S_{t}^{G-}=D^{i}\left(P_{t}^{i}\right)+S_{t}^{i}+X_{t}^{i}+\Delta S_{t}^{G+} .
$$

Volume released for the PDS, denoted $\Theta$, is assumed to be constant and, based on data from the previous decade, equal to 12 million tons per year. The model allows for the possibility that existing public stocks $\left(S_{t}^{G}+\Delta S_{t}^{G+}\right)$ may not always be sufficient to cover the quantities required for the PDS. If procurement at MSP is not enough to supply the PDS, the remaining quantities are assumed to come from open-market purchases. Such purchases need not be represented here, because they are analogous to a transfer operated by the government. Stock releases therefore obey the following equation:

$$
\Delta S_{t}^{G-}=\min \left(\Theta, S_{t}^{G}+\Delta S_{t}^{G+}\right)
$$

Because releases for the PDS are not state-contingent and the MSP tends to be set at a high level, procurement levels are often high relative to requirements. Without a policy for systematic releases above the established stocking norms, the PDS releases alone would not prevent explosive stock levels. As discussed, the government occasionally resorts to exporting grain from its stocks to reduce excessive accumulation and deterioration (Dorosh and Rashid 2013). ${ }^{4}$ For that reason, India is assumed to export its public stocks when they reach a certain threshold. These exports are denoted as $X^{S^{G}}$. They are defined by:

$$
X_{t}^{S^{G}}=\max \left(0, S_{t}^{G}+\Delta S_{t}^{G+}-\Delta S_{t}^{G-}-\bar{S}^{G}\right),
$$

where $\bar{S}^{G}$ is the threshold that triggers public stock exports. Based on past behaviour, the government reaches that threshold when the end-of-season stock equals 25 million tons (Fig. 1). Since public stocks are not exported at the Indian market price, these exports do not affect

\footnotetext{
${ }^{4}$ Excessive stocks are also disposed of domestically through open market sales, but mostly for stabilizing the domestic market before the new harvest arrival (Kozicka et al., 2015, p.30). It is not possible to represent such releases in an inter-annual model.
} 
the Indian market equilibrium, only the RoW market equilibrium, which is adjusted accordingly:

$$
A_{t}^{\mathrm{w}}+X_{t}^{\mathrm{i}}+X_{t}^{S^{G}}=D^{\mathrm{w}}\left(P_{t}^{\mathrm{w}}\right)+S_{t}^{\mathrm{w}}+X_{t}^{\mathrm{w}} .
$$

Public storage is an additional state variable of the problem. Its transition equation is

$$
S_{t}^{G}=S_{t-1}^{G}+\Delta S_{t-1}^{G+}-\Delta S_{t-1}^{G-}-X_{t-1}^{S^{G}} .
$$

The cash flows at period $t$ of the storage policy are defined by the sum of three terms: the cost of storing for one period, the outlays from wheat purchases and releases, and the benefits from any export of stocks, which gives the following expression:

$$
\begin{aligned}
\operatorname{Cos}_{t}^{i, S}=k^{i}\left(S_{t}^{G}\right. & \left.+\Delta S_{t}^{G+}-\Delta S_{t}^{G-}-X_{t}^{S^{G}}\right) \\
& +P_{t}^{i}\left(\Delta S_{t}^{G+}-\Delta S_{t}^{G-}\right) \\
& -X_{t}^{S^{G}}\left(P_{t}^{w}-\theta_{i, w}\right)
\end{aligned}
$$

It can be positive or negative depending on whether the government is releasing or accumulating stocks. This formula assumes that stocks are released at the Indian market price, with the loss on sales under the PDS attributed to the PDS. This assumption enables the cost of storage to be disentangled from the cost of food subsidies (not calculated here), which is the difference between the market price and the subsidized price.

\subsubsection{Trade policy}

Through its trade policy for wheat, India appears to have consistently tried to offset short-run world price movements, even as the country's domestic price policy broadly accommodates the long-run trends. Often this outcome is achieved through discretionary decisions to restrict exports or to apply price minima that reduce wheat exports. The model captures the essence of these discretionary trade policy decisions by using a tariff that is adjusted in opposition to shortrun changes in world price. The power of the tariff $(1+\tau)$ is assumed to be captured by an isoelastic model of the relevant border price:

$$
\begin{aligned}
& T_{\mathrm{t}}^{M}=\alpha_{M}\left(P_{t}^{w}+\theta_{w, i}\right)^{\beta}, \\
& T_{t}^{X}=\alpha_{X}\left(P_{t}^{w}-\theta_{i, w}\right)^{\beta},
\end{aligned}
$$

where $T^{M}$ and $T^{X}$ are the power of the tariffs applied to imports and exports, $\beta$ is the elasticity of border protection with respect to border prices, and $\alpha_{M}$ and $\alpha_{X}$ are scale parameters.

To determine the extent of trade policy interventions, an error-correction model between India's producer price and world price is estimated, and the short-run price transmission elasticity is retained as an estimate of $1+\beta$ (see supplemental appendix, Section A, for details 
on the estimation). The estimated elasticity of border protection is equal to -0.76 . Over the long term, India's domestic price has fluctuated around the world price without any systematic deviations, so the scale parameters, $\alpha_{M}$ and $\alpha_{X}$, are calibrated such that there is no protection at steady state.

To incorporate these aspects of the trade policy, the trade equations become

$$
\begin{aligned}
& X_{t}^{w} \geq 0 \perp\left(P_{t}^{w}+\theta_{w, i}\right) T_{t}^{M} \geq P_{t}^{i}, \\
& X_{t}^{i} \geq 0 \perp P_{t}^{i} \geq\left(P_{t}^{w}-\theta_{i, w}\right) T_{t}^{X} .
\end{aligned}
$$

This trade policy generates the following outlays:

$$
\begin{aligned}
\operatorname{Cost}_{t}^{i, T r}= & \left(T_{t}^{X}-1\right) X_{t}^{\mathrm{i}}\left(P_{t}^{w}-\theta_{i, w}\right) \\
& -\left(T_{t}^{M}-1\right) X_{t}^{\mathrm{w}}\left(P_{t}^{w}+\theta_{w, i}\right) .
\end{aligned}
$$

\subsection{Optimal price stabilization policies}

An optimal stabilization policy is designed based on the assumption that government is committed to following a state-contingent policy that maximizes expected intertemporal welfare. Two potential instruments of stabilization are considered: storage and trade. For convenience, the analysis adopts a primal approach by assuming that government takes control of storage and trade, but the resulting behaviour could also be achieved through incentives for private agents. Where government controls storage and trade, in the absence of private stock holders, the terms accounting for stock holder surplus in the social welfare function are actually equal to public storage costs. The remaining public costs (which may be negative) are associated with trade policy, defined by

$$
\operatorname{Cost}_{t}^{i, T r}=X_{t}^{i}\left(\theta_{i, w}+P_{t}^{i}-P_{t}^{w}\right)+X_{t}^{w}\left(\theta_{w, i}+P_{t}^{w}-P_{t}^{i}\right)
$$

To determine the optimal levels of trade and storage, the government maximizes the expected sum of the discounted instantaneous social welfare function

$$
\begin{gathered}
E_{0} \sum_{t=0}^{\infty} \delta^{t}\left[-d^{i} \frac{P_{t}^{i^{1+\alpha^{i}}}}{1+\alpha^{i}}+P_{t}^{i} A_{t}^{i}-a^{i} \bar{H}_{t}^{i}-\frac{b^{i} \bar{H}_{t}^{i^{2}}}{2}-\left(k^{i}+P_{t}^{i}\right) S_{t}^{i}-\operatorname{Cos}_{t}^{i, T r}\right. \\
\left.-\frac{K}{2}\left(P_{t}^{i}-\bar{P}^{i}\right)^{2}\right]
\end{gathered}
$$


subject to the constraints imposed by private agents' behaviour and market equilibrium - that is, eqs (2), (3), (5), and (6). ${ }^{5}$ The optimal policy problem is laid out mathematically in the supplemental appendix (Section B). The first-order conditions of this problem are derived following the methodology developed in Marcet and Marimon (2011); for details about the method and the interpretation of its first-order conditions, see Gouel (2013a). Solving this optimal policy problem produces storage and trade rules that are contingent on the state of the system. The policy under consideration is under commitment, which implies that at some initial date the government chooses, once and for all, the state-contingent rules. The policy rules corresponding to policies under commitment are generally time-inconsistent, as they would differ from the rules that would be chosen ex post once any effects of the decisions on prior expectations could be neglected. Given the time-inconsistency of the optimal policy, the policy rules depend not only on the two natural state variables (availability in both countries) but also on their past realizations, which are summarized by two lagged Lagrange multipliers in the first-order conditions laid out in the appendix.

\subsection{Optimal simple rules}

Gaining an understanding of the best policy options is important, but fully optimal policies have drawbacks. They are highly dependent on the economic setting for which they are optimized, and they are difficult to implement, because they depend on state variables that are modeldependent and not observable (lagged Lagrange multipliers). These limitations are avoided by following the approach of Gouel (2013b) to design optimal simple rules of price stabilization, which are rules of public behaviour that provide simple feedback between observable variables and policy instruments, but whose parameters are chosen to maximize welfare. As before, two instruments of intervention - trade and storage policy-are considered. In the literature, the most popular simple rules are price-band rules, but they are not good candidates for optimal simple rules. They are extremely nonlinear, making the choice of parameters extremely sensitive to the assumed model and its calibration. Their behaviour is far from the behaviour of an optimal storage policy, and the probability of stockouts and collapse when stocks reach unmanageable levels is very high (for additional discussion of this issue, see Wright, 2011, and Gouel, 2013b).

Previous studies (Gouel, 2013b; Gouel and Jean, 2015) have found that optimal storage policies tend to behave similarly to a competitive storage rule. Building on the idea that private stock holders are good at reacting to evolving economic situations but may provide too little stabilization in the absence of intervention, the prospects for a very simple policy to encourage

\footnotetext{
5 This optimization programme implicitly assumes that India's government takes into account its market power over the rest of the world when designing its optimal stabilization policy. Alternatively, it is possible to design an optimal policy with India neglecting the possibility to manipulate its terms of trade. This leads to very similar results.
} 
more private storage (specifically, a constant subsidy to private storage in India) are considered here. ${ }^{6}$ Such a subsidy should increase stock levels, which in turn would stabilize prices. As noted, the resulting storage rule could also be implemented through public stocks. Accounting for the constant subsidy $\zeta$, the stock holders' arbitrage equation (3) becomes for India

$$
S_{t}^{i} \geq 0 \perp P_{t}^{i}+k^{i}(1-\zeta)-\delta E_{t} P_{t+1}^{i} \geq 0
$$

To facilitate the interpretation of results, the subsidy is expressed as a percentage of physical storage costs $k^{i}$. In this case, the public costs associated with the storage subsidy are defined by

$$
\operatorname{Cost}_{t}^{i, S}=k^{i} \zeta S_{t}^{i}
$$

In the absence of an upper bound on stock levels, a necessary condition for a stationary rational expectations equilibrium to exist is for storage to be costly. For instance, if price stays constant (that is, at a steady state), storage should not be profitable and so should not take place, which can be stated using eq. (25) as

$$
\begin{gathered}
\bar{P}^{i}+k^{i}(1-\zeta)-\delta \bar{P}^{i}>0 \\
\zeta<1+\frac{(1-\delta) \bar{P}^{i}}{k^{i}}
\end{gathered}
$$

This value will be used in the welfare maximization as an upper bound on $\zeta$ to ensure convergence to a stationary equilibrium.

Trade policies are assumed to be set following the rule in current use, indicated in eqs (18) and (19). However, $\beta$, the elasticity of border protection with respect to border price, will be chosen to maximize welfare.

Taking into account the public costs defined by eqs (22) and (26), the optimal simple rules are the rules defined by the parameters $\zeta$ and $\beta$ that maximize

$$
\begin{gathered}
E_{0} \sum_{t=0}^{\infty} \delta^{t}\left\{-d^{i} \frac{P_{t}^{i^{1+\alpha^{i}}}}{1+\alpha^{i}}+P_{t}^{i} A_{t}^{i}-a^{i} \bar{H}_{t}^{i}-\frac{b^{i} \bar{H}_{t}^{i^{2}}}{2}-\left[k^{i}(1-\zeta)+P_{t}^{i}\right] S_{t}^{i}-\operatorname{Cost}_{t}^{i}\right. \\
\left.-\frac{K}{2}\left(P_{t}^{i}-\bar{P}^{i}\right)^{2}\right\}
\end{gathered}
$$

subject to eqs (2), (3), (5), (6), (18)-(21), and (25).

${ }^{6}$ The effect of a subsidy to private storage is also analysed among others in Glauber et al. (1989), and Gardner and López (1996). 


\section{Results}

\subsection{Calibration}

The model focuses on the stochastic aspects of India's wheat market. The year 2012 is used as the reference point for the steady-state equilibrium, and the values of all variables are set at their 2012 levels. Table 1 describes the steady-state equilibrium values of the main variables.

At the steady state, India is self-sufficient, and no trade occurs with the RoW. This means that India's prices will oscillate between cif and fob prices, depending on the occurrence of domestic and foreign production shocks. Recently India's domestic price has been close to and occasionally below the fob price. To reflect the fact that on average India is more likely to export rather than to import, the steady-state price is calibrated closer to the fob price than the cif price.

Based on detrended production, the random component of wheat production is estimated to have a standard deviation of 0.035 in both regions, and to be independent across time and space. The equality of production variability between the RoW composite and the single country of India is unusual and likely reflects the diversity of production regions within India and the fact that almost all of India's wheat is grown under irrigation. In general, the volatility of output would be expected to be much higher for an individual country than for the RoW composite, because of the low correlations between the outputs of different countries.

Annual interest rates are assumed to be the same for each region, at 5\%. Choosing appropriate storage costs is important, as this variable significantly affects the results. For private stock holders in India and in the RoW, per unit storage charges are assumed to be US\$ 22.40 per ton, based on estimates of worldwide benchmark private sector costs from a recent World Bank study (World Bank and FAO, 2012). ${ }^{7}$ Combined with the opportunity cost of the grain, this physical storage cost entails an overall storage cost at steady state of $17.5 \%$ of India's domestic price. Public storage costs in India appear to be much higher, at around US\$ 87 per

\footnotetext{
${ }^{7}$ Private storage costs in India are competitive relative to the global benchmark used here. Estimates of storage costs from National Bulk Handling Corporation, a private entity, are equivalent to about US\$16 per ton in general, but a bit higher at about $\$ 19.2$ in the National Capital Region or port locations (Anil Choudhary, Managing Director and CEO, personal communication). Data from IFC from recent modern grain silos projects indicate a cost of storage at about US\$ 19.75 per ton in Punjab, where the private developer of storage provides land, and $\$ 11.5$ per ton in Madhya Pradesh, where land is provided by the government. The Food Corporation of India has fixed ceiling rates for storage rental from private providers under the 'Private Entrepreneurs Guarantee' (PEG) scheme at Rs 4.78 per quintal per month, which translates to only US\$ 9.56 per ton (see Warehousing Development and Regulatory Authority website at http://wdra.nic.in/FinalBook.pdf, last accessed December 2, 2015). Finally, the base storage rental rates established by the Central Warehousing Corporation for private sector bidding for wheat storage under normal access conditions (that is flat terrain with easy access such as may be expected in the national capital region) are about US\$ 18 per ton (see http://www.cewacor.nic.in/Docs/commodity_tariff_201314.pdf, last accessed December 1, 2015).
} 
ton. ${ }^{8}$ However, since it is not clear how the accounting of storage costs is done by the Food Corporation of India, it is possible that these costs do not match conceptually to the storage costs in the model. Because of this uncertainty, a sensitivity analysis is carried out in Section 6.4.2. It should be noted that these costs neglect the cost of storage losses. Anecdotal evidence appears to indicate that such losses are large because storage conditions are inadequate, ${ }^{9}$ but the actual rate at which stocks deteriorate is unknown. For private storage costs, following (28), the maximum storage subsidy compatible with a stable steady state is equal to 1.4. Similarly, for public storage costs of US\$ 87 per ton, the maximum subsidy is 1.1 .

Indian import costs are based on international trade costs and port charges from Pursell et al. (2009). For export costs, the port charges are the same as for imports, but international trade costs are assumed to be smaller (2/5), as India exports wheat to less distant countries than those from which it sources its imports (Pursell et al., 2009, do not provide information on export costs). These trade costs exclude domestic transport costs.

The selection of appropriate elasticities is challenging-the literature is uncertain on this point-but crucial, as they drive many results. The literature on commodity price dynamics, which implies relatively low demand elasticities (Cafiero et al., 2011; Roberts and Schlenker, 2013), puts the RoW demand elasticity at -0.12 . An elasticity this low is unlikely to be valid for a lower-middle-income country such as India, however, where demand for this staple food is expected to be more elastic than the world average (Muhammad et al., 2011). Based on recent estimates by Kumar et al. (2011), a price elasticity of -0.3 was ultimately selected.

The supply elasticity at steady state is 0.2 , in line with the commonly used supply elasticity for wheat. The combination of this elasticity and of target values of price and production at steady state makes it possible to determine $a^{r}$ and $b^{r}$. The rational expectations storage model is approximated numerically (see the supplemental appendix, Section C, for details).

To evaluate social welfare and to design optimal policies, a weight is assigned to wheat price volatility in the social welfare function. No ready source of information is available for this policy parameter. As explained in Section 4.2, the parameter characterizing the social preference for price stability, $K$, could be interpreted as a second-order approximation of the equivalent variation for a risk-averse consumer, reflecting income and risk-aversion effects. This interpretation is used to guide the choice of relevant values, and consumers are assumed to spend $10 \%$ of their income on wheat. The steady-state values are used as the reference levels for demand and price. In seeking to define optimal policies, several values will be considered

\footnotetext{
${ }^{8}$ The economic cost of the Food Corporation of India available at http://fciweb.nic.in/finances/view/9, accessed February 11, 2015. For the financial year 2012/13, the annual rate of buffer stock carrying cost is estimated to be Rs 4,744.6 per ton. The average exchange rate from April to March was 54.35 Rs/US\$, which leads to an annual storage cost of US\$ 87.3 per ton.

9 'As crops rot, millions go hungry in India,' Reuters, July 1, 2012; '2,400 MT wheat rotting in govt granaries for past 2 years,' The Times of India, May 7, 2013.
} 
for $K$ to illustrate how policies vary when different welfare weights are assigned to price volatility. The difference between the parameters of relative risk aversion and income elasticity $(R-v)$ is varied from 0 to 12 . In unpacking current policies (6.2) and exploring fully optimal policies (6.3), the analysis retains $R-v=6$.

\subsection{Unpacking current policies}

This section characterizes the effects of the current storage and trade policies described in Section 5.1. Three scenarios are considered as alternatives to laissez-faire: a scenario with storage policy alone, a scenario with trade policy alone, and a scenario combining both policies. These policy experiments make it possible to unpack the contribution of each policy. The experiment relying only on storage policy assumes that India liberalizes its wheat trade, including the use of export subsidies to dispose of excess stocks. Similarly, the trade policy assumption implies no public storage.

In interpreting the results that follow, a word of caution is in order regarding the limitations of rational expectations storage models with respect to what they aim to represent and how well they achieve that aim. First, the only motivation for private storage assumed here is intertemporal arbitrage. While that is an important motive per se, it excludes many other important transactional or precautionary motives that could explain much actual stock-holding behaviour (Williams, 1986). Given that trade is instantaneous in the model, there is also no reason to accumulate stocks to account for time to ship (Coleman, 2009). These motivations are quantitatively important, as evidenced by historical stock data. A purely speculative motive would allow for regular stockouts, while at the world level the stock-to-use ratio never decreases much below 20\%. Because of this focus on one motive for storage, the simulated statistics on private stock levels are likely to underestimate real storage. Second, stabilization policies are represented as free of any flaws (except potentially in their design): the policies perfectly follow the decided rules without any delay or discretionary political interventions. Such a perfect representation of India's wheat policies is likely to overestimate the achievable price stabilization. Third, for the sake of tractability, the model focuses on two main sources of price volatility: production shocks in India and in the RoW. This focus excludes other sources of volatility such as shocks to exchange rates, and prices of oil and other agricultural commodities. Overall, the model aims to capture the most important types of spatial and intertemporal arbitrage, but the inherent complexity of this issue implies that the model should not be considered a forecasting tool but rather a means of quantitatively illustrating the consequences of each policy option.

Table 2 presents the effects of the various instruments of current policy on the asymptotic distribution of the model. ${ }^{10}$ Storage and trade policies alone provide similar levels of price

\footnotetext{
${ }^{10}$ See supplementary appendix for details about the simulation method.
} 
stabilization, with storage decreasing the coefficient of variation a little more than trade policy. The ability of storage to achieve such price stability in an open economy comes from the fact that India's domestic price is often between the fob and cif margins. This assessment is confirmed by the fact that world price volatility is little affected by a storage-only policy. The fundamental difference between the stability provided by trade and storage concerns extreme prices. The storage policy truncates low prices almost perfectly, but it cannot prevent all price spikes and does little to reduce the occurrence of high prices. The explanation for this outcome lies with the rule governing the storage policy. The policy is not designed to operate as a price band, with stocks released to prevent high prices; rather, stocks are released in a fixed amount every period to supply the PDS. In contrast, the trade policy mostly truncates high domestic prices. Together both policies are extremely effective in stabilizing the domestic price, because of the complementarity between the instruments. Trade policy prevents public stocks from being exported when the world price spikes, preventing any leakage from the operation of the storage policy to the world market.

The policies have little effect on India's wheat production. Since producers are assumed to be risk neutral in their behaviour and their marginal cost linear in the production level, their production decisions depend not on price volatility but on the expectations of prices times the yield shock (eq. (2)), which vary little between the policies considered, as evidenced by the mean price changes.

Under all scenarios, the model allows for the possibility of competitive domestic storage in India. In practice, stock holders find few profit opportunities under scenarios that include active trade and storage stabilization policies, since these policies rarely allow speculators to cover their costs. A significant level of private storage arises only when both storage and trade policies are removed. These policies do have an effect on private storage in the RoW, however. By increasing world price volatility, the trade policy option increases the profit opportunities from speculation and raises the mean stock level. The storage policy crowds out part of foreign storage, as it diminishes world price volatility slightly. The combination of the two policies is dominated by the effects of the trade policy and storage increases worldwide.

Public stocks reach a much higher level when storage policy is combined with trade policy. This outcome is explained by the high degree of insulation permitted by trade policy. Combined with a trade policy of this type, public stock accumulation is almost perfectly insensitive to foreign availability, since the foreign price does not influence the domestic price. Storage releases for the PDS are constant and do not differ across scenarios. Only the releases for direct export to dispose of excessive stocks differ, as they are not allowed in the storage-only policy. For that reason, differences in average stock levels are explained by the levels of stock accumulation. Without trade policy, Indian domestic prices are often driven above the intervention price (equal to the steady-state price) by foreign demand. Counter-cyclical 
adjustments of trade policies prevent this from happening and trigger frequent public storage interventions to defend the MSP. In this situation, which is not far from that of a closed economy, defending a floor price equal to the steady-state price is sure to lead to very large stocks.

These differences in stock levels translate to large differences in government outlays. The discounted average cost of a storage policy alone is US\$ 382 million, while it is US\$ 874 million when combined with trade policy (Table 3 ). Table 3 also displays the $5^{\text {th }}$ and $95^{\text {th }}$ percentiles of the corresponding annual cash flow. The cash flow for the storage policy is alternatively positive or negative depending on changes in stock levels. In both situations, $5 \%$ of the time, the accumulation of public stocks costs more than US\$2,021 million. The storage policy is much more costly than the trade policy. On average, trade subsidies are compensated by taxes, and trade is so much reduced by these interventions that actual outlays are low.

Table 3 also decomposes the welfare results for each component. Welfare components are expressed as deviations from laissez-faire and normalized as a percentage of the steady-state value of consumption of the corresponding country. Notably, when both policies are combined, storage costs reach on average 3.7 percent of the commodity budget share. Without retaining a very high weight given to food price stability, this cost is likely to exceed gains from lower price instability.

It is also worth noting that since the trade policy insulates the domestic market from the RoW, public stock accumulation mostly reacts to domestic and not worldwide availability. One consequence is that a large accumulation of public stocks may coexist with export restrictions, which could be interpreted as the simultaneous application of both the brake and the accelerator-the price is lowered by the export restrictions and raised by the stock accumulation. This combination is not problematic in itself, however, because it can arise as an outcome of optimal trade and storage policies (Gouel and Jean, 2015). In the Gouel and Jean framework of a small economy, this combination occurs at medium world price levels because stock accumulation does not increase the domestic price when the country is exporting, and the subsequent release of stocks will cause prices to fall in periods of scarcity.

In the present framework, however, the combination of export restrictions and stock accumulation is more likely to create problems. Insulated from the world price, stock accumulation does not respond to global market conditions, allowing stocks to accumulate even as the price spikes in the RoW. In addition, in the absence of effective release rules, the accumulation of stocks does not guarantee more stable future prices.

\subsection{Optimal policy versus simple rules}

This section compares outcomes under the laissez-faire model, the application of an optimal policy, and the use of optimal simple rules. Because the costs of public storage are very high in 
India, it is challenging to find a role for storage in an optimal stabilization policy. Here it is assumed that grain is stored by private agents, and the precise stock level is optimally decided. The issue of optimal storage at a high public cost is left for discussion in Section 6.4.

Total welfare gains for India under the optimal policy represent $0.46 \%$ of the value of steady-state wheat consumption in India (Table 4). When compared with the optimal policy, the optimal simple rules prove to be very good, achieving $86 \%$ of the welfare gains of the optimal policy. One important difference between the results of these policies is that under the optimal policy, the coefficient of variation of price in India is almost four percentage points lower than under simple rules, despite similar stock levels.

Under simple rules, private storage is incentivized by an optimal constant subsidy equal to $97 \%$ of physical storage costs. Under optimal policy, the government controls storage, but it is possible to determine the state-contingent subsidy that would make private stock holders behave similarly to the optimal policy. The behaviour of the equivalent optimal state-contingent subsidy would be as follows. The subsidy would be above $100 \%$, close to a normal situation (i.e., close to steady state), but could fall below 97\% when availability in India falls below normal. A state-contingent subsidy would decrease with domestic or foreign availability, because when scarcity prevails it is better to let producers increase the production level than to incentivize stockpiling, because there is not enough wheat to stockpile.

The simple-rules trade policy is counter-cyclical to border price, with an optimal constant elasticity of -0.49 , and adjusts similarly for exports and for imports. Compared to the laissezfaire arrangement, the simple-rules trade policy has a strong anti-trade bias, significantly reducing exports and imports. The optimal trade policy does not restrict trade as much as the simple rules; it reduces exports but increases imports. By design, the optimal trade policy is a function of both world and domestic availability, not just world price as under the simple-rules policy. In consequence, instead of just insulating India from the world market, the optimal policy exploits the world market to increase domestic stability. With the optimal policy, imports are subsidized to decrease the domestic price when domestic availability is low, whereas imports are subsidized under the simple-rules policy only when the world price spikes. This explains why imports increase under the optimal policy, while they decrease under the simple rules.

Despite these limitations, the simple-rules policy does very well, achieving almost all of the welfare gains offered by the optimal policy. ${ }^{11}$ The good performance of the simple rules is not limited to the specific value of $K$. Table 5 shows that for other positive weights given to price stability in the welfare function, simple rules achieve a high share of the gains from the

\footnotetext{
${ }^{11}$ For more on the interpretation of the optimal policy, see Gouel (2013a) for a closed economy situation and Gouel and Jean (2015) for a small-open country situation.
} 
optimal policy. The good performance of the simple rules stems from the fact that they leverage the ability of a private marketing system to arbitrate intertemporal and spatial profit opportunities by providing stock holders and traders' incentives to make more socially beneficial arbitrages. They cannot do as well as the optimal policies, because they are less flexible and because they refrain from exploiting the world market for stabilizing the domestic market (the trade-policy rule is meant to protect the domestic market from world price fluctuations not to dump domestic fluctuations on the world market). Since policies under simple rules are easier to analyse and to implement than optimal policies, the remaining discussion will focus on the simple-rules policies.

\subsection{Optimal simple rules of stabilization}

The optimal simple storage policy allows for two interpretations. In the most obvious one, government provides incentives to private stock holders through the constant subsidy. Another interpretation is that the optimal storage subsidy also provides a storage rule that could be implemented by a public authority such as the Food Corporation of India, although (as noted in the calibration) storage costs are much higher for public than for private storage. For that reason, optimal storage will differ depending on whether it is undertaken by the private sector or by a public agency. The following sections seek to determine the optimal policies for both configurations, but the emphasis is on privately operated storage, given that it is much more cost-effective.

\subsubsection{Storage by private stock holders}

For $R-v=0$, no weight is assigned to price volatility in social welfare. This choice does not imply that the optimal policy is free trade, because India can improve its social welfare by manipulating its terms of trade. For the trade policy, the chosen simple rule is not particularly suited to maximize welfare by manipulating the terms of trade. Export or import subsidies would not make sense, because both lead to a deterioration in the terms of trade. Following Bagwell and Staiger (1990), a trade policy aimed at exploiting the terms of trade should be based on the potential trade volume, and thus on the difference between Indian and RoW availability, rather than on RoW price. Although the simple rules are not designed to take into account the motivation for terms-of-trade manipulation, trade interventions are not negligible when price volatility is unweighted (see Table 5, first column). The optimal elasticity of border protection $(\beta)$ is -0.17 , which already reduces price volatility from $14.39 \%$ in laissez-faire to $12.77 \%$. The optimal storage subsidy $(\zeta)$ is low, equal to $2 \%$ of physical storage cost. One interpretation for this non-zero storage subsidy is that an increased storage level could lead to more exports and so to larger potential gains from terms-of-trade manipulation.

When a positive weight is given to price stability in India's social welfare function, the optimal simple rules provide significant price stability. The two parameters that characterize 
the rules, $\beta$ and $\zeta$, increase significantly for the initial departures from a zero weight on volatility, but they progressively flatten as the risk weight is further increased. It follows from their limited progression that price volatility decreases only slightly once $R-v$ exceeds 9 . The implications are shown by calculating the cost of the policy and the welfare gains from price stabilization. The mean stock level and the cost of storage increase linearly with the preference for price stability (Table 5), while price volatility decreases at a much slower rate. The effect of storage policy on price stability decreases with existing stock levels, because stocks have to be held for longer and to be bought at higher prices.

To illustrate the complementarity between the two instruments, Table 6 displays statistics on Indian prices and the parameters of the policy rules when instruments are optimized separately. The price stability achieved by using the policy instruments separately is much lower than when they are combined. The optimal coefficient of insulation from world price, $\beta$, is very close to its value when combined with storage. This is not the case for the subsidy to private storage, which is lower than when combined with trade policy. This lower value can be explained by two things. First, by reducing domestic price volatility, the trade policy reduces the incentives for private storage; these lower incentives are compensated by the subsidy to storage when both instruments are used, but this compensation is not needed when using storage policy alone. Second, the benefits from the storage policy leak to the world market without trade policy, reducing the benefits compared to those from a combined intervention.

\subsubsection{Storage by a public agency}

If the agent receiving the storage subsidy is a public agency, the results are very different. The combination of a storage cost of US\$ 87 per ton and a 5\% interest rate implies at steady state an overall cost to store for one year equal to $53.5 \%$ of the price. A private stock holder with these high costs would not carry any stocks in laissez-faire in the absence of a storage subsidy. Indeed, it is not possible to break even with such high storage costs.

In this scenario, results depend on maintaining the assumption that private stock holders are authorized to operate (without subsidy) alongside the public agency. If they are authorized to operate, it is optimal to not subsidize public storage, and the results are identical to the results obtained from the optimal trade policy alone in Table 6. In the absence of private stock holders, it is optimal to subsidize storage, but the overall level of storage remains very small because its high cost discourages its use as a policy instrument (Table 7) —even with significant storage subsidies (between $60 \%$ and $77 \%$ of storage cost). These subsidies are just sufficient to make public storage profitable but not to induce a significant level of storage. With such high storage costs, it is better for India to rely on trade and private storage abroad than on domestic public storage. 
Since it is difficult to economically justify public storage at the current high costs, Table 7 , also considers what optimal rules would be if public costs were lower at $\$ 40$ per ton, that is between private storage costs and current public costs. Albeit high, costs at US\$ 40 per ton are low enough to justify a significant level of public storage when a sufficient weight is given to price volatility. The amount of storage subsidy is significant, as it covers almost all storage costs, but the insulation parameters are not significantly affected by the change in public storage costs.

\section{Conclusions}

The analysis presented here has relied on a rational expectations storage-trade model to represent current policies for managing wheat price volatility in India and propose alternative stabilization policies. Representing current policies is a challenge, because they appear to be highly discretionary. To capture their essence, they have been represented as simple rules, defined as functions of world and domestic conditions. The alternative stabilization policies are derived from the maximization of a social welfare function that includes a motivation for price stability. The treatment of alternative policies contains two innovations for developing price stabilization policies: it designs optimal price stabilization policies for a large-country case, and it considers simple rules for stabilization and demonstrates how closely their effects can approximate those of a fully optimal policy.

India's policies have been very effective in stabilizing the domestic wheat price, but their high costs raise concerns about whether the costs are exceeding the benefits. The current policy is costly for two main reasons: trade and storage policy are not coordinated, and the storage policy appears to follow a buy-and-hold strategy. Large stock levels are held for long periods, but stock releases are insufficient to dampen domestic price rises; instead, the government has occasionally had to dispose of wheat stocks on the world market.

Another key food policy issue for India is the cost of public grain storage. The current costs, declared by the Food Corporation of India, are four times higher than long-run costs estimated for other countries by World Bank and FAO (2012). Such high costs make it extremely difficult to justify public storage in India on economic grounds, as it would be much less costly to rely on domestic private storage or on world trade and storage abroad. For that reason, the alternative policies considered here are based on providing sufficient incentives to induce the more costefficient private stock holders to store grains in a socially optimal way. However, these policies could as well be implemented by the Food Corporation of India if the problem of high storage costs is resolved and it is able to manage its stocks in a competitive manner as an optimizing private storer would with the same incentives.

The fully optimal policy determines the levels of storage and trade that maximize total welfare, whereas the optimal simple rules of stabilization adjust the parameters from 
predetermined rules in optimizing the welfare function. These simple rules are a constant subsidy to private storage (as storage policy) and tariffs defined by an isoelastic function of border price (as trade policy). A notable result from the model is that the optimal simple rules achieve welfare gains approaching those obtained by implementing a fully optimal policy. Under simple policy rules, private storage is incentivized to reach stock levels above the competitive level. Since private storage reacts in appropriate ways to price behaviour, it combines well with the trade policy, a result that is extremely difficult to achieve with a priceband programme (or its variants).

One important conclusion of the analysis is that it endorses the broad approach adopted by India of using a combination of trade and storage policies to target price stability. A second important conclusion is that, this combination of policies could be fine-tuned to significantly increase India's total welfare and significantly reduce its storage costs by adopting a more rulesbased food policy. As price stabilization policies do not directly target the underlying market failures, which are often thought to be related to the economic agents' lack of capacity to cope with shocks (Gouel, 2014), they are not regarded as first-best policies. Yet price stabilization policies hold considerable appeal for many policy makers who have clearly exhibited a dislike for price volatility, and certain market failures may prevent the first-best policy options from achieving their goals.

If price stabilization policies are to be used, however, it is important to identify how best to use them. In India, given the current circumstances, significant cost savings (through a combination of storage and trade costs) could be made without any significant net loss in "pure" welfare (defined as the sum of producers or consumers surplus) through a less insulating trade policy implemented in conjunction with storage rules that are similar to, but above, competitive storage levels. These gains are predicated on efficient private sector storage, however. The current public costs of storage do not justify any level of public storage in the country without significant overall loss in welfare.

A final consideration is that this work has neglected the rest of the world's reaction to India's wheat policies, although that reaction may not be without consequence. The recent food crisis (and prior crises) demonstrated that when one country institutes trade policies to insulate from the world market, the desire of other countries to use insulating policies is reinforced, and the overall effectiveness of such policies is attenuated (Martin and Anderson, 2012; Anderson et al., 2014). By definition this collective action problem cannot be solved by one country alone, but the problem may nevertheless matter for the design of an individual country's policies. If the effectiveness of trade policies is limited by partners' reactions, the implication is that storage policy may play a more important role in domestic prices stabilization than was found in this analysis. 


\section{Supplementary material}

Supplementary material (the Appendix) is available online at the OUP website.

\section{Funding}

This work was supported by the World Bank Knowledge for Change Program [TF010230]; by the South Asia Food and Nutrition Security Initiative [SAFANSI] managed by the World Bank with contributions from the Governments of United Kingdom and Australia; by the Consultative Group for International Agricultural Research research program on Policies Institutions, and Markets [PIM to W.M.]; and by the European Union's Seventh Framework Programme FP7/2007-2011 [290693 FOODSECURE to C.G.].

\section{Acknowledgements}

The authors gratefully acknowledge the feedback and comments from Prachi Mishra (Senior Economist) and her team at the Office of the Economic Adviser, Ministry of Finance, Government of India. The study has benefited from feedback and comments from the participants at the Indian Econometric Society Meetings in Mumbai, in December 2013, and the Food Price Volatility Workshop organized by the Global Development Network, the IMF, and the OCP Policy Center at Rabat, Morocco, in February, 2014, where preliminary model results were presented. The authors also benefited from feedback from Brian Wright, Sergiy Zorya, and Julian Lampietti, and from discussions and inputs from Donald Larson and Maros Ivanic. The findings, interpretations, and conclusions expressed in this paper are those of the authors and do not necessarily reflect the views of the Executive Directors of The World Bank or the governments they represent. The World Bank does not guarantee the accuracy of the data included in this work.

\section{References}

Anderson, K., Ivanic, M., and Martin, W. (2014) Food Price Spikes, Price Insulation, and Poverty, in J.-P. Chavas, D. Hummels, and B. D. Wright (eds) The Economics of Food Price Volatility, University of Chicago Press, Chicago, IL. Chapter 8 (pp. 311-39).

Bagwell, K. and Staiger, R.W. (1990) A Theory of Managed Trade, The American Economic Review, 80,779-95.

Basu, K. (2011) India's Foodgrain Policy: An Economic Theory Perspective, Economic and Political Weekly, 46, 37-45.

Cafiero, C., Bobenrieth, E.S.A., Bobenrieth, J.R.A., and Wright, B.D. (2011) The Empirical Relevance of the Competitive Storage Model, Journal of Econometrics, 162, 44-54.

Coleman, A. (2009) Storage, Slow Transport, and the Law of One Price: Theory with Evidence from Nineteenth-Century U.S. Corn Markets, Review of Economics and Statistics, 91, 332-50.

Demeke, M., Pangrazio, G., and Maetz, M. (2009) Country Responses to the Food Security Crisis: Nature and Preliminary Implications of the Policies Pursued, Food and Agriculture Organization (FAO), Rome. 
Dorosh, P.A. and Rashid, S. (2013) Trade Subsidies, Export Bans, and Price Stabilization: Lessons of Bangladesh-India Rice Trade in the 2000s, Food Policy, 41, 103-11.

Ganesh-Kumar, A., Mehta, R. Pullabhotla, H., Prasad, S.K., Ganguly, K., and Gulati, A. (2012) Demand and supply of cereals in India: 2010-2025, Discussion Paper No. 1158, International Food Policy Research Institute (IFPRI), Washington, DC.

Gardner, B. L., and López, R. (1996) The Inefficiency of Interest-Rate Subsidies in Commodity Price Stabilization, American Journal of Agricultural Economics, 78, 508-16.

Glauber, J. W., Helmberger, P. G., and Miranda, M. J. (1989) Four Approaches to Commodity Market Stabilization: A Comparative Analysis, American Journal of Agricultural Economics, 71, 326-37.

Gouel, C. (2013a) Optimal Food Price Stabilisation Policy, European Economic Review, 57, 118-34.

Gouel, C. (2013b) Rules versus Discretion in Food Storage Policies, American Journal of Agricultural Economics, 95, 1029-44.

Gouel, C. (2014) Food Price Volatility and Domestic Stabilization Policies in Developing Countries, in J.-P. Chavas, D. Hummels, and B. D. Wright (eds) The Economics of Food Price Volatility, University of Chicago Press, Chicago, IL. Chapter 7 (pp. 261-306).

Gouel, C. and Jean, S. (2015) Optimal Food Price Stabilization in a Small Open Developing Country, The World Bank Economic Review, 29, 72-101.

Gulati, A., Jain, S., and Hoda, A. (2013) Farm trade: tapping the hidden potential, Discussion Paper No. 3, Commission for Agricultural Costs and Prices, Department of Agriculture $\backslash \&$ Cooperation, Ministry of Agriculture, Government of India, New Delhi.

Kozicka, M., Kalkuhl, M., Saini, S., and Brockhaus, J. H. (2015) Modeling Indian Wheat and Rice Sector Policies, Working Paper No. 295, Indian Council for Research on International Economic Relations, New Delhi.

Kumar, P., Kumar, A., Parappurathu, S., and Raju, S.S. (2011) Estimation of Demand Elasticity for Food Commodities in India, Agricultural Economics Research Review, 24, 1-14.

Larson, D.F., Lampietti, J., Gouel, C., Cafiero, C., and Roberts, J. (2014) Food Security and Storage in the Middle East and North Africa, The World Bank Economic Review, 28, 48-73.

Marcet, A. and Marimon, R. (2011) Recursive contracts, Working Paper No. 2011/15, European University Institute, Florence.

Martin, W. and Anderson, K. (2012) Export Restrictions and Price Insulation During Commodity Price Booms, American Journal of Agricultural Economics, 94, 422-27.

Muhammad, A., Seale, J.L., Meade, B., and Regmi, A. (2011) International Evidence on Food Consumption Patterns: An Update Using 2005 International Comparison Program Data, Technical Bulletin No. 1929, United States Department of Agriculture, Economic Research Service, Washington, DC.

Pursell, G., Gulati, A., and Gupta, K. (2009) Distortions to Agricultural Incentives in India, in K. Anderson and W. Martin (eds) Distortions to Agricultural Incentives in Asia, World Bank, Washington, DC. Chapter 10 (pp. 339-78).

Roberts, M.J., and Schlenker, W. (2013) Identifying Supply and Demand Elasticities of Agricultural Commodities: Implications for the US Ethanol Mandate, American Economic Review, 103, 2265-95.

Srinivasan, P.V and Jha, S. (2001) Liberalized Trade and Domestic Price Stability: The Case of Rice and Wheat in India, Journal of Development Economics, 65, 417-41.

Turnovsky, S.J., Shalit, H., and Schmitz, A. (1980) Consumer's Surplus, Price Instability, and Consumer Welfare, Econometrica, 48, 135-52. 
USDA (United States Department of Agriculture). (2013) Production, Supply, and Distribution Online, http://www.fas.usda.gov/psdonline/, accessed September 5, 2013.

Williams, J.C. (1986) The Economic Function of Futures Markets, Cambridge University Press, Cambridge.

Williams, J.C. and Wright, B.D. (1991) Storage and Commodity Markets, Cambridge University Press, Cambridge.

World Bank and FAO (Food and Agriculture Organization). (2012) The Grain Chain: Food Security and Managing Wheat Imports in Arab Countries. Washington, DC.

Wright, B.D. (2011) The Economics of Grain Price Volatility, Applied Economic Perspectives and Policy, 33, 32-58. 


\section{Tables}

Table 1 Model calibration values

\begin{tabular}{|c|c|c|c|}
\hline \multicolumn{2}{|c|}{ Calibration target at deterministic steady state } & India & RoW \\
\hline \multicolumn{2}{|c|}{ Consumption (million tons) } & 86.51 & 589.55 \\
\hline \multicolumn{2}{|c|}{ Production (million tons) } & 86.51 & 589.55 \\
\hline \multicolumn{2}{|c|}{ Price $(U S \$ / t)$} & 188.33 & 200 \\
\hline Parameter & Economic interpretation & India & RoW \\
\hline $\operatorname{std}\left(\epsilon^{r}\right)$ & Standard deviation of production shocks & \multicolumn{2}{|c|}{0.035} \\
\hline$\delta$ & Discount factor & \multicolumn{2}{|c|}{0.95} \\
\hline $\boldsymbol{k}^{r}$ & Physical storage cost (US\$/t) & $22.4^{\mathrm{a}} / 87^{\mathrm{b}}$ & 22.4 \\
\hline $\boldsymbol{\theta}_{r, s}$ & Export trade cost $(\mathrm{US} \$ / \mathrm{t})$ & 35 & 65 \\
\hline$\alpha^{r}$ & Demand elasticity & -0.3 & -0.12 \\
\hline$a^{r}$ & Intercept of marginal cost function & -717.45 & -761.90 \\
\hline$b^{r}$ & Slope of marginal cost function & 10.37 & 1.62 \\
\hline$M S P$ & Minimum support price $(\mathrm{US} \$ / \mathrm{t})$ & 188.33 & \\
\hline$\overline{\boldsymbol{S}}^{G}$ & $\begin{array}{l}\text { Stock threshold for exports from public stocks } \\
\text { (million tons) }\end{array}$ & 25 & \\
\hline$\Theta$ & Volume released for PDS (million tons) & 12 & \\
\hline
\end{tabular}

Notes: Consumption and production targets are obtained as the trend value in 2012 after HP filtering (smoothing parameter of 400) on the underlying data from USDA (2013). The standard deviation of production shocks is determined as the standard deviation of filtered production values.

${ }^{a}$ For private storage.

${ }^{\mathrm{b}}$ For public storage. 
Table 2 Unpacking current policies, statistics (quantities in million tons)

\begin{tabular}{lcccc}
\hline Variable & & & & Both \\
\hline India price (US\$/t) & Laissez-faire & Trade policy & Storage policy & $\begin{array}{c}\text { instruments } \\
\quad \text { Mean }\end{array}$ \\
CV $(\%)$ & 196.2 & 190.5 & 197.6 & 189.7 \\
$\quad$ Quantile 10\% & 14.39 & 10.68 & 10.12 & 3.13 \\
$\quad$ Quantile 90\% & 164.5 & 166.1 & 188.3 & 188.3 \\
RoW price (US\$/t) & 230.9 & 218.2 & 221.7 & 188.3 \\
$\quad$ Mean & 200.5 & 202.3 & 199.7 & 202.5 \\
CV (\%) & 20.70 & 23.99 & 19.57 & 23.28 \\
Quantile 10\% & 160.2 & 160.2 & 159.8 & 160.3 \\
$\quad$ Quantile 90\% & 258.8 & 269.2 & 251.6 & 272.3 \\
India demand & & & & \\
$\quad$ Mean & 85.77 & 86.39 & 85.41 & 86.33 \\
CV (\%) & 3.98 & 3.11 & 2.58 & 0.84 \\
Mean India production & 87.13 & 86.66 & 87.37 & 86.62 \\
Mean India storage & & & & \\
$\quad$ Private & 0.10 & 0.02 & 0.00 & 0.00 \\
$\quad$ Public & & & 4.21 & 10.38 \\
Mean RoW private & 4.05 & 4.78 & 3.69 & 4.75 \\
storage & & & & \\
Mean exports & 1.38 & 0.27 & 1.96 & 0.18 \\
Mean imports & 0.02 & 0.00 & 0.01 & 0.00 \\
\hline
\end{tabular}


Table 3 Welfare changes and public cost of current policies

\begin{tabular}{|c|c|c|c|c|}
\hline Variable & Laissez-faire & Trade policy & Storage policy & $\begin{array}{c}\text { Both } \\
\text { instruments }\end{array}$ \\
\hline & \multicolumn{4}{|c|}{ Welfare changes as percentage of consumption value } \\
\hline \multicolumn{5}{|l|}{ India welfare } \\
\hline $\begin{array}{l}\text { Consumers' } \\
\text { surplus }\end{array}$ & \multicolumn{3}{|c|}{ surplus } & 2.14 \\
\hline $\begin{array}{l}\text { Producers' } \\
\text { surplus }\end{array}$ & & -2.65 & 1.42 & -2.22 \\
\hline Total cost & & 0.08 & -2.18 & -3.62 \\
\hline Storage cost $\mathrm{t}^{\mathrm{a}}$ & & 0.00 & -2.18 & -3.74 \\
\hline Trade cost & & 0.08 & 0.00 & 0.13 \\
\hline \multicolumn{5}{|l|}{$($ for $R-v=6)$} \\
\hline Total welfare & & 0.24 & -1.80 & -3.04 \\
\hline \multirow[t]{2}{*}{ RoW welfare } & & -0.01 & 0.01 & -0.01 \\
\hline & \multicolumn{4}{|c|}{ Cost of the policies on the asymptotic distribution (million US\$) } \\
\hline \multicolumn{5}{|l|}{ Storage policy } \\
\hline Mean & 0 & 0 & 382 & 874 \\
\hline Quantile 5\% & 0 & 0 & $-1,322$ & -595 \\
\hline Quantile 95\% & 0 & 0 & 2,021 & 2,659 \\
\hline \multicolumn{5}{|l|}{ Trade policy } \\
\hline Mean & 0 & -13 & 0 & -26 \\
\hline Quantile 5\% & 0 & -72 & 0 & -160 \\
\hline Quantile 95\% & 0 & 6 & 0 & 64 \\
\hline
\end{tabular}


Table 4 Optimal policy versus simple rules for $R-v=6$ (quantities in million tons)

\begin{tabular}{lccc}
\hline Variable & Laissez-faire & Optimal policy & Simple rules \\
\hline India & & & \\
Mean price (US\$/t) & 196.2 & 190.9 & 191.7 \\
Price CV (\%) & 14.39 & 4.78 & 8.53 \\
Mean stock & 0.10 & 0.95 & 0.95 \\
Mean exports & 1.38 & 0.85 & 0.62 \\
Mean imports & 0.02 & 0.32 & 0.00 \\
RoW & & & \\
Mean price (US\$/t) & 200.5 & 201.9 & 201.7 \\
Price CV (\%) & 20.70 & 22.69 & 22.48 \\
India welfare & & & \\
Consumers' surplus & & 1.66 & 1.70 \\
Producers' surplus & & -1.79 & -1.84 \\
Total cost & & 0.02 & 0.05 \\
Storage cost & -0.09 & -0.12 \\
$\quad$ Trade cost & & 0.11 & 0.17 \\
Cost of volatility & & 0.57 & 0.49 \\
Total welfare & & 0.46 & 0.40 \\
RoW welfare & & -0.01 & -0.01 \\
\hline
\end{tabular}


Table 5 Optimal simple rules when private agents hold stocks (quantities in million tons)

\begin{tabular}{lccccc}
\hline & \multicolumn{5}{c}{$R-v$} \\
\cline { 2 - 5 } Variable & 0 & 3 & 6 & 9 & 12 \\
\hline Insulation parameter $(\beta)$ & -0.17 & -0.41 & -0.49 & -0.53 & -0.55 \\
Storage subsidy $(\zeta)$ & 0.02 & 0.72 & 0.97 & 1.08 & 1.15 \\
Share of welfare achieved by & & & & & \\
optimal simple rules (\%) & 77.8 & 85.8 & 86.3 & 86.1 & 85.7 \\
India & & & & & \\
Mean price (US\$/t) & 194.6 & 192.3 & 191.7 & 191.4 & 191.3 \\
Price CV (\%) & 12.77 & 9.91 & 8.53 & 7.76 & 7.16 \\
Mean stock & 0.08 & 0.48 & 0.95 & 1.31 & 1.68 \\
Mean exports & 1.09 & 0.73 & 0.62 & 0.56 & 0.53 \\
Mean imports & 0.01 & 0.00 & 0.00 & 0.00 & 0.00 \\
RoW & & & & & \\
Mean price (US\$/t) & 201.0 & 201.5 & 201.7 & 201.9 & 202.0 \\
Price CV (\%) & 21.40 & 22.25 & 22.48 & 22.59 & 22.62 \\
$\quad$ Mean stock & 4.21 & 4.44 & 4.47 & 4.48 & 4.49 \\
India welfare & & & & & \\
Consumers' surplus & 0.64 & 1.53 & 1.70 & 1.77 & 1.80 \\
Producers' surplus & -0.72 & -1.68 & -1.84 & -1.91 & -1.94 \\
Total cost & 0.10 & 0.11 & 0.05 & 0.01 & -0.04 \\
$\quad$ Storage cost & 0.00 & -0.05 & -0.12 & -0.17 & -0.22 \\
$\quad$ Trade cost & 0.10 & 0.16 & 0.17 & 0.18 & 0.18 \\
Cost of volatility & 0.00 & 0.21 & 0.49 & 0.79 & 1.10 \\
Total welfare & 0.02 & 0.17 & 0.40 & 0.66 & 0.92 \\
\hline
\end{tabular}


Table 6 Optimal simple rules when instruments are considered separately

\begin{tabular}{|c|c|c|c|c|c|}
\hline \multirow[b]{2}{*}{ Variable } & \multicolumn{5}{|c|}{$R-v$} \\
\hline & 0 & 3 & 6 & 9 & 12 \\
\hline & \multicolumn{5}{|c|}{ Optimal trade policy $($ when $\zeta=0)$} \\
\hline Insulation parameter $(\beta)$ & -0.17 & -0.40 & -0.48 & -0.52 & -0.56 \\
\hline \multicolumn{6}{|l|}{ India price } \\
\hline Mean $(\mathrm{US} \$ / \mathrm{t})$ & 194.6 & 192.6 & 192.0 & 191.7 & 191.5 \\
\hline $\mathrm{CV}(\%)$ & 12.79 & 11.24 & 10.92 & 10.79 & 10.71 \\
\hline \multicolumn{6}{|l|}{ RoW price } \\
\hline Mean (US\$/t) & 201.0 & 201.6 & 201.8 & 201.9 & 201.9 \\
\hline \multirow[t]{2}{*}{$\mathrm{CV}(\%)$} & 21.40 & 22.40 & 22.75 & 22.95 & 23.13 \\
\hline & \multicolumn{5}{|c|}{ Optimal storage policy (when $\beta=0$ ) } \\
\hline Storage subsidy $(\zeta)$ & -0.09 & 0.49 & 0.73 & 0.85 & 0.93 \\
\hline \multicolumn{6}{|l|}{ India price } \\
\hline Mean $(\mathrm{US} \$ / \mathrm{t})$ & 196.2 & 196.0 & 196.1 & 196.3 & 196.5 \\
\hline $\mathrm{CV}(\%)$ & 14.46 & 13.61 & 12.85 & 12.28 & 11.85 \\
\hline \multicolumn{6}{|l|}{ RoW price } \\
\hline Mean $(\mathrm{US} \$ / \mathrm{t})$ & 200.5 & 200.3 & 200.2 & 200.1 & 200.1 \\
\hline $\mathrm{CV}(\%)$ & 20.72 & 20.56 & 20.41 & 20.27 & 20.16 \\
\hline
\end{tabular}


Table 7 Optimal simple rules when stocks are managed by a public agency and private storage is prohibited

\begin{tabular}{|c|c|c|c|c|c|}
\hline \multirow[b]{2}{*}{ Variable } & \multicolumn{5}{|c|}{$R-v$} \\
\hline & 0 & 3 & 6 & 9 & 12 \\
\hline & \multicolumn{5}{|c|}{ Public storage cost of US\$ 87 per ton } \\
\hline Insulation parameter $(\beta)$ & -0.17 & -0.40 & -0.48 & -0.54 & -0.57 \\
\hline Storage subsidy $(\zeta)$ & 0.60 & 0.62 & 0.69 & 0.77 & 0.77 \\
\hline \multicolumn{6}{|l|}{ India price } \\
\hline Mean $(\mathrm{US} \$ / \mathrm{t})$ & 194.6 & 192.7 & 192.0 & 191.6 & 191.5 \\
\hline $\mathrm{CV}(\%)$ & 13.03 & 11.42 & 11.00 & 10.69 & 10.62 \\
\hline \multicolumn{6}{|l|}{ RoW price } \\
\hline Mean $(\mathrm{US} \$ / \mathrm{t})$ & 201.0 & 201.6 & 201.8 & 201.9 & 202.0 \\
\hline $\mathrm{CV}(\%)$ & 21.43 & 22.41 & 22.78 & 23.02 & 23.15 \\
\hline \multirow{2}{*}{$\begin{array}{l}\text { Mean India stock (million } \\
\text { tons) }\end{array}$} & 0.01 & 0.01 & 0.02 & 0.06 & 0.06 \\
\hline & \multicolumn{5}{|c|}{ Public storage cost of US\$ 40 per ton } \\
\hline Insulation parameter $(\beta)$ & -0.17 & -0.40 & -0.49 & -0.54 & -0.56 \\
\hline Storage subsidy $(\zeta)$ & 0.14 & 0.48 & 0.83 & 0.93 & 1.00 \\
\hline \multicolumn{6}{|l|}{ India price } \\
\hline Mean (US\$/t) & 194.6 & 192.6 & 191.7 & 191.3 & 191.1 \\
\hline CV $(\%)$ & 13.03 & 11.18 & 9.71 & 8.89 & 8.22 \\
\hline \multicolumn{6}{|l|}{ RoW price } \\
\hline Mean (US\$/t) & 201.0 & 201.6 & 201.7 & 201.8 & 201.9 \\
\hline $\mathrm{CV}(\%)$ & 21.43 & 22.41 & 22.62 & 22.78 & 22.84 \\
\hline $\begin{array}{l}\text { Mean India stock (million } \\
\text { tons) }\end{array}$ & 0.01 & 0.06 & 0.42 & 0.69 & 0.99 \\
\hline
\end{tabular}


Figures
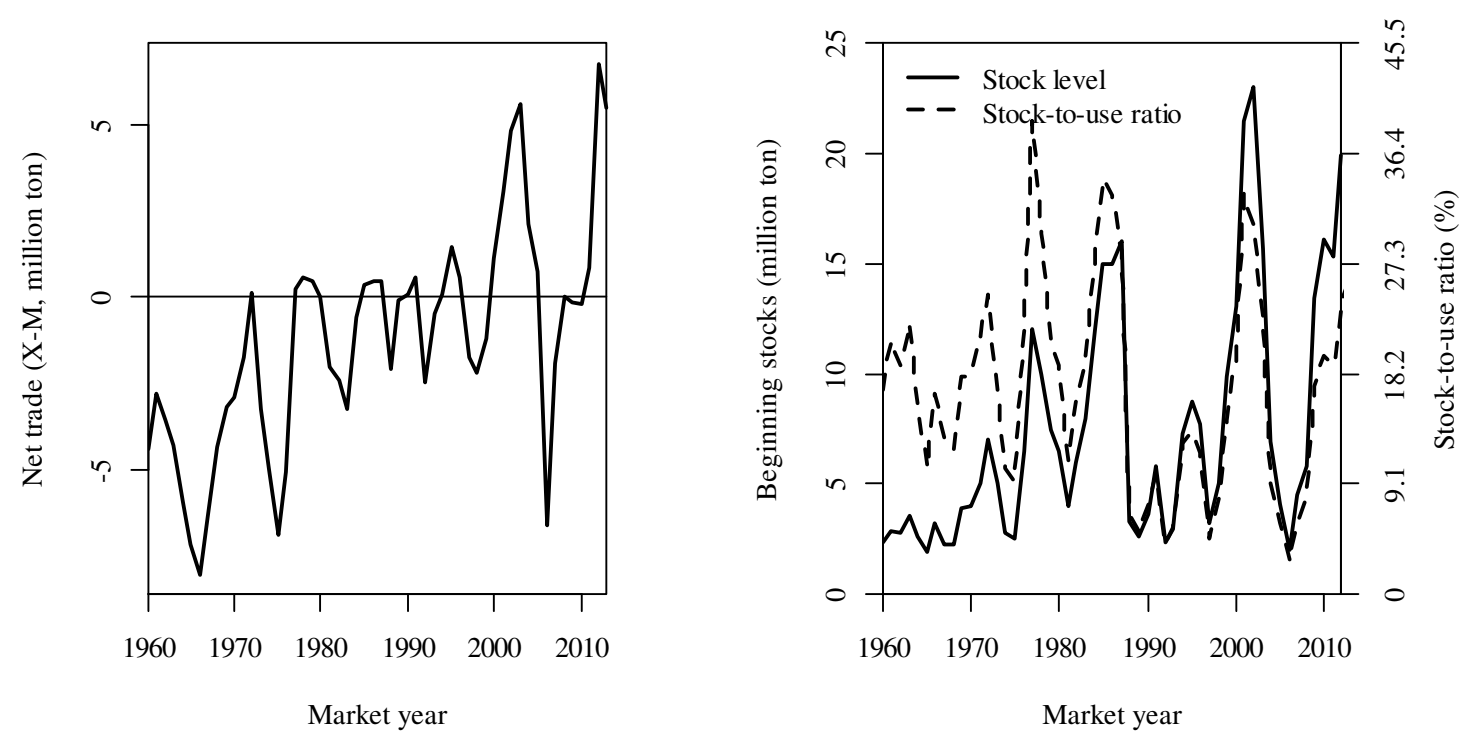

Fig. 1. Wheat trade and stock levels in India (source: USDA, 2013) 